\section{Commentary: Two decades of innovation, leadership, and overcoming challenges, but more lies ahead}

\section{Douglas Z. Liou, MD}

Since its formation in 1997, the Thoracic Surgery Residents Association (TSRA) has had tremendous influence on cardiothoracic surgery training, as detailed by Brescia and colleagues. ${ }^{1}$ Considering the organization is run solely by surgeons in training under the guidance of the Thoracic Surgery Directors Association, the list of accomplishments is exceptional, particularly over the past decade. Among them are more than a dozen widely used educational publications, including review books, reference guides, and test preparation material. A podcast series created by TSRA offers free access to more than 100 unique cardiothoracic surgery topics and has more than 175,000 listens across the globe. More recently, the organization has focused on facilitating peer-to-peer mentorship among medical students, surgeons in training, and seasoned faculty through collaborative events at national meetings. These efforts provide a different avenue to attract young talent to our specialty, foster intellectual growth, and stimulate innovation.

Many changes in cardiothoracic surgery occurred during the early TSRA era owing to declining interest in the specialty that largely stemmed from concerns about longterm job security.,3 During that time of uncertainty, TSRA played an active role in helping to identify the problem through data collection and research studies involving surgical trainees across North America. ${ }^{4,5}$ Targeted interventions were undertaken over the next decade, including the introduction of an integrated cardiothoracic surgery residency program allowing direct matriculation from medical school that has returned cardiothoracic surgery training to a

From the Division of Thoracic Surgery, Department of Cardiothoracic Surgery, Stanford University School of Medicine, Stanford, Calif.

Disclosures: The author reported no conflicts of interest.

The Journal policy requires editors and reviewers to disclose conflicts of interest and to decline handling or reviewing manuscripts for which they may have a conflict of interest. The editors and reviewers of this article have no conflicts of interest.

Received for publication Sept 16, 2020; revisions received Sept 16, 2020; accepted for publication Sept 17, 2020; available ahead of print Sept 28, 2020.

Address for reprints: Douglas Z. Liou, MD, Division of Thoracic Surgery, Department of Cardiothoracic Surgery, Stanford University School of Medicine, 300 Pasteur Dr, Falk Building, Stanford, CA 94305 (E-mail: dliou@stanford.edu).

J Thorac Cardiovasc Surg 2021;162:928-9

$0022-5223 / \$ 36.00$

Copyright (c) 2020 by The American Association for Thoracic Surgery

https://doi.org/10.1016/j.jtcvs.2020.09.080

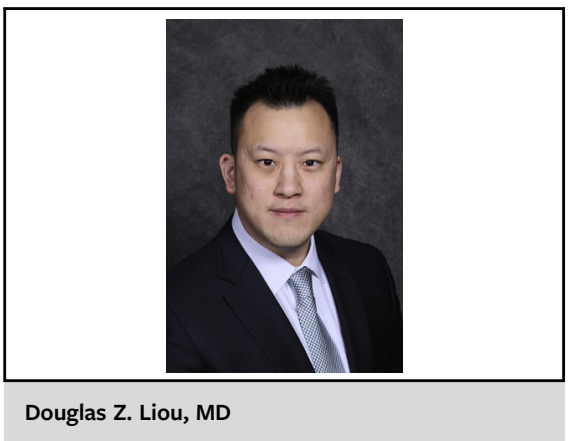

CENTRAL MESSAGE

The Thoracic Surgery Residents

Association has an impressive

record of enhancing education

and providing leadership, and is

poised to help guide the next

generation of cardiothoracic

surgery trainees.

preeminent state. ${ }^{6}$ Since then, TSRA has maintained its vital role by continually assessing the quality and components of the cardiothoracic surgery education structure. ${ }^{7,8}$ One could argue that few, if any, other resident-led associations have had a comparable influence on the overall training and outlook of their specialty during such a daunting period.

Challenges facing the current generation of cardiothoracic surgeons will differ significantly from those prior. Events in our society during the past few years-2020 in particular-have illustrated vividly many of the problems that medicine is facing, including health disparities among socioeconomic groups, gender inequality, and racial bias. Diversity, equity, and inclusion are part of the TSRA mission, and it is not surprising that the organization is already involved in examining some of these issues within our specialty. ${ }^{9,10}$ Although it is uncertain how these challenges will ultimately influence the practice of cardiothoracic surgery, we have come to expect that the TSRA will take the lead on confronting the issues.

\footnotetext{
References

1. Brescia AA, Lou X, Louis C, Blitzer D, Coyan GN, Han JJ, et al. The Thoracic Surgery Residents Association: past contributions, current efforts, and future directions. J Thorac Cardiovasc Surg. 2021;162:917-27.e5.

2. Salazar JD, Ermis P, Laudito A, Lee R, Wheatley GH, Paul S, et al. Cardiothoracic surgery resident education: update on resident recruitment and job placement. Ann Thorac Surg. 2006;82:1160-5.

3. Vaporciyan AA, Reed CE, Erikson C, Dill MJ, Carpenter AJ, Guleserian KJ, et al Factors affecting interest in cardiothoracic surgery: survey of North American general surgery residents. Ann Thorac Surg. 2009;87:1351-9.
} 
4. Sarkaria IS, Carr SR, Maciver RH, Whitson BA, Joyce DL, Stulak J, et al. The 2010 Thoracic Surgery Residents Association workforce survey report: a view from the trenches. Ann Thorac Surg. 2011;92:2062-71.

5. Cooke DT, Kerendi F, Mettler BA, Boffa DJ, Mehall JR, Merrill WH, et al. Update on cardiothoracic surgery resident job opportunities. Ann Thorac Surg. 2010;89:1853-9.

6. Bui J, Bennett WC, Long J, Strassle PD, Haithcock B. Recent trends in cardiothoracic surgery training: data from the National Resident Matching Program. J Surg Educ. September 11, 2020 [Epub ahead of print].

7. Tchantchaleishvili V, Lapar DJ, Stephens EH, Berfield KS, Odell DD, Denino WF. Current integrated cardiothoracic surgery residents: a
Thoracic Surgery Residents Association survey. Ann Thorac Surg. 2015 99:1040-7.

8. Nguyen TC, Terwelp MD, Stephens EH, Odell DD, Loor G, Lapar DJ, et al. Resident. The perceptions of 2-year versus 3-year cardiothoracic training programs. Ann Thorac Surg. 2015;99:2070-6.

9. Stephens EH, Robich MP, Walters DM, Denino WF, Aftab M, Tchantchaleishvili V, et al. Gender and cardiothoracic surgery training: specialty interests, satisfaction, and career pathways. Ann Thorac Surg. 2016;102:200-6.

10. Ceppa DP, Dolejs SC, Boden N, Phelan S, Yost KJ, Doningon J, et al. Sexua harassment and cardiothoracic surgery: \#UsToo? Ann Thorac Surg. 2020;109: 1283-8.
See Article page 917

\section{Commentary: The changing role of the Thoracic Surgery Residents Association over time}

\author{
Yota Suzuki, MD, and Ikenna Okereke, MD
}

The Thoracic Surgery Residents Association (TSRA) is a robust and active organization led by trainees. As described by the current members of the TSRA in their article, ${ }^{1}$ the TSRA was established in 1997 with a mission of representing the interests and needs of resident physicians in thoracic surgery specialty. The role and activity of the TSRA has expanded over the years, in concert with the changing nature of thoracic training programs.

The introduction of integrated thoracic programs has had a significant influence on the training structure for thoracic surgeons. The age and level of surgical experience of trainees has decreased significantly, ${ }^{2}$ and the gap between faculty and junior thoracic residents has widened. A communication from the TSRA sent to a postgraduate year 6 through 8 in 1997 would likely focus on very different ideas than an e-mail message sent to a

\footnotetext{
From the Division of Cardiothoracic Surgery, University of Texas Medical Branch, Galveston, Tex

Disclosures: The authors reported no conflicts of interest.

The Journal policy requires editors and reviewers to disclose conflicts of interest and to decline handling or reviewing manuscripts for which they may have a conflict of interest. The editors and reviewers of this article have no conflicts of interest.

Received for publication Aug 30, 2020; revisions received Aug 30, 2020; accepted for publication Sept 1, 2020; available ahead of print Sept 4, 2020.

Address for reprints: Ikenna Okereke, MD, Division of Cardiothoracic Surgery, University of Texas Medical Branch, 301 University Blvd, Galveston, TX 77555 (E-mail: ikokerek@utmb.edu).

J Thorac Cardiovasc Surg 2021;162:929-30

$0022-5223 / \$ 36.00$

Copyright (C) 2020 by The American Association for Thoracic Surgery

https://doi.org/10.1016/j.jtcvs.2020.09.003
}

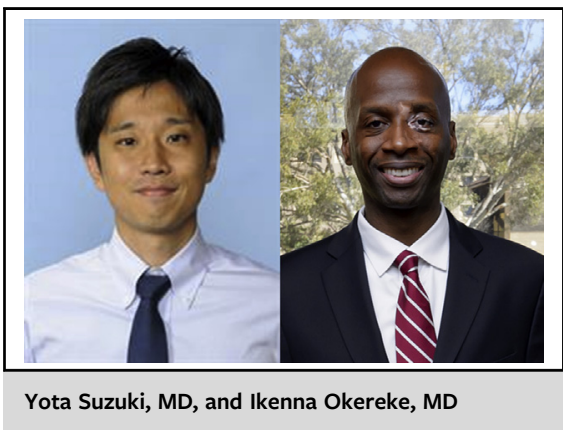

CENTRAL MESSAGE

The Thoracic Surgery Residents Association has played a major role in providing guidance to trainees since its inception in 1997. It has adapted its function as training has changed over time.

postgraduate year 1 during 2020. The authors address the role of the TSRA in reducing this gap and acclimating young trainees to become better able to succeed during their training. TSRA offers online publications targeting young trainees, mentorship by senior residents at multiple institutions, and a variety of social media podcasts and programming. Although there has been a high level of satisfaction expressed by integrated program residents with their programs, ${ }^{3}$ supporting their training with help from organizations like the TSRA will maximize the benefit of training.

In addition, the ongoing pandemic has shown that the use of virtual conferencing will play a pivotal role in training over the next decade. The TSRA has responded by scheduling multiple virtual meetings this year. To assist students who are applying to thoracic surgery training programs, the 